\title{
Altered Hematological and Biochemical Parameters in Schoolchildren Living in an Agricultural Community of Merida State, Venezuela
}

Leticia Miranda-Contreras ${ }^{1 *}$, Jesus Alfonso Osuna ${ }^{2}$, Ibis Cruz ${ }^{1}$, Yasmin Morales ${ }^{1}$, Nolis Camacho ${ }^{3}$, Rosanna Cicchetti ${ }^{3}$, Iraida Salazar ${ }^{4}$, Melisa

Colmenares ${ }^{1}$, Alirio Balza', Leisalba Zavala ${ }^{1}$ and Beluardi Sanchez ${ }^{1}$

${ }^{1}$ Electron Microscopy Center "Dr. Ernesto Palacios Prü", University of Los Andes, Merida, Venezuela

${ }^{2}$ Laboratory of Andrology, Faculty of Medicine, University of Los Andes, Merida, Venezuela

${ }^{3}$ Department of Pediatric Endocrinology, University Hospital of Los Andes, Merida, Venezuela

${ }^{4}$ Hematology Unit, Department of Medicine, University Hospital of Los Andes, Merida, Venezuela

\begin{abstract}
Epidemiological studies have found that children living in a pesticide treated farmland have higher risk of developing cancer or other serious health problems. Their exposure to pesticides could be limited by periodic health assessments; however, there are few biomarkers for pesticide exposure. The aim of this work was to examine the effects of chronic exposure to pesticides on hematological and biochemical parameters in farm-resident children compared to urban-resident control children. A cross-sectional study was conducted in 72 farm schoolchildren and 41 controls; a follow-up study was done two years later on 20 participants. The children underwent a clinical examination, nutritional assessment, and blood sampling for complete hemogram and biochemical analysis of liver and renal functions, lipid and glucose metabolism, plasma cholinesterase, thyroid hormones and total antioxidant capacity. A prevalence of malnutrition and undernutrition were found in both exposed and control children. The most important hematological results were thrombocytosis in $48 \%$ of farm children, increased mean lymphocyte and monocyte counts, and decreased mean neutrophil counts compared to control. Butyrylcholinesterase activity was diminished in $35 \%$ of farm children. Alterations in biochemical parameters were observed between exposed and control groups, however, most of the results were within normal limits, except for the significant decrease in total antioxidant capacity. Follow-up study 2 years later showed normalized platelet and lymphocyte counts, however, decreased neutrophil counts was still observed. This study demonstrates that children living in an agricultural community are exposed to the health hazards of pesticides. Undernutrition and improper dental hygiene affect children's overall health status and are likely to increase their vulnerability to toxic effects of pesticides.
\end{abstract}

Keywords: Farm children; Hematological parameters; Biochemical parameters; Pesticide exposure

\section{Introduction}

Over the last decades, several studies have dealt on the vulnerability of children to the toxic effects of pesticides because of developmental, dietary and physiological factors [1,2]. Prenatal or childhood exposure to organophosphate (OP) and organochlorine (OC) pesticides has been documented to induce neurotoxic effects, which may cause impairments in the child's neurobehavioral development [3-6]. Exposure to atmospheric OP and pyrethroid pesticides through inhalation was associated with respiratory symptoms consistent with childhood asthma $[7,8]$. Pesticide exposure has been implicated as a possible contributing factor in the pathogenesis of several types of childhood cancer, including those of lymphatic and hematopoietic systems, soft tissue sarcoma, brain and stomach cancer [9-12]. In children, cancer is the number one cause of death by disease; in fact, it is responsible for more deaths than all other diseases combined [13]. Leukemia is the most common childhood malignancy, representing about $30 \%$ of all cancers diagnosed in children under 15 years of age in industrialized countries [14]. The annual incidence of cancer in Venezuelan children and adolescents younger than 15 years was dominated by leukemia (37\% of total cancer cases), followed by malignant brain tumors (12\%) and lymphomas (11\%) [15]. Thus, concern has been raised with regard children residing near pesticide-treated farmlands, or whose parents are agricultural workers, because they have higher risk of developing cancer or other serious health problems $[9,11,12,16-18]$. OP metabolites were seen at much higher levels for farmworkers and their children than non-farmworkers and their children during the agricultural season when OPs were in use [19].

In developing countries, the severity of pesticide exposures and toxicities are largely overlooked in the general population. The unique behavior of children and their metabolic rate often place them at risk for absorption of higher doses of pesticides from contaminated environments in comparison with adults. Their exposure to pesticides could be limited by periodic health assessments; however, there are few biomarkers for pesticide exposure. A widely accepted biomarker of exposure is the inhibition of serum cholinesterase activity caused by OPs and carbamates (CBs) [20,21]. Some studies have indicated that variations in hematological and biochemical profiles could predict and prevent health risks of pesticide exposure [22]. Ismail et al. [23] revealed significant differences in hematological, renal and hepatic indices in children and adolescent pesticide applicators compared with control group. Aside from these parameters, various studies evaluated the variation in oxidant/antioxidant status in experimental animals [24-26] as well as in aquatic organisms [27-29] to monitor the effects of chronic exposure to OP and phosphonate pesticides. Many pesticides share common cytotoxic mechanisms involving mitochondrial dysfunction,

*Corresponding author: Leticia Miranda-Contreras, Universidad de Los Andes, Centro de Microscopia Electronica "Dr. Ernesto Palacios Prü", Calle 32 entre Avenidas 4 y Tulio Febres Cordero, Bulevar de Los Estudiantes, Merida 5101, Venezuela, Tel: 582742403166/3160; Fax: 582742403156; E-mail: Imiranda@ula.ve (or)miranda.leticia@gmail.com

Received January 16, 2017; Accepted January 25, 2017; Published January 30 , 2017

Citation: Miranda-Contreras L, Osuna JA, Cruz I, Morales Y, Camacho N, et al (2017) Altered Hematological and Biochemical Parameters in Schoolchildren Living in an Agricultural Community of Merida State, Venezuela. J Environ Anal Toxicol 7 : 431. doi: 10.4172/2161-0525.1000431

Copyright: (c) 2017 Miranda-Contreras L, et al. This is an open-access article distributed under the terms of the Creative Commons Attribution License, which permits unrestricted use, distribution, and reproduction in any medium, provided the original author and source are credited. 
Citation: Miranda-Contreras L, Osuna JA, Cruz I, Morales Y, Camacho N, et al. (2017) Altered Hematological and Biochemical Parameters in Schoolchildren Living in an Agricultural Community of Merida State, Venezuela. J Environ Anal Toxicol 7: 431. doi: 10.4172/21610525.1000431

Page 2 of 7

which causes the generation of reactive oxygen species (ROS) and dysregulation of the oxidant/antioxidant system, thereby leading to oxidative stress $[30,31]$. The antioxidant responsive elements provide multiple defense and detoxification capacity in cells and tissues of the organism. Studies have shown an inverse association between total antioxidant capacity (TAC) and the risk of chronic diseases [32-34]; therefore, assessment of the antioxidant defense may be important for improving the health of individuals and of the general population.

In this research, we examined the effects of pesticide toxicity on hematological and biochemical parameters, plasma cholinesterase activity, thyroid gland hormones and TAC in schoolchildren living in an agricultural community of Merida state, Venezuela. The indiscriminate use of pesticides in this region has led to the contamination of both superficial and drinking water resources [35-37] as well as crops $[38,39]$. Previous reports from our group have confirmed the potential impact on male reproductive function of farmworkers occupationally exposed to pesticides [20,40]. Despite the widespread environmental contamination, no study has examined the health risks of children living in the region. The aim of this work was to examine the effects of chronic exposure to pesticides on hematological and biochemical parameters in farm-resident children compared to urban-resident control children.

\section{Materials and Methods}

\section{Study area}

Cross-sectional and longitudinal studies were carried out during school time periods, between 2012 and 2014, at the Municipality of Rivas Davila, Merida state, Venezuela. This region is located at $1700 \mathrm{~m}$ above sea level, and because of its temperate climate, farming is possible all year round. Due to intensive agricultural production, there is a great demand for pesticide use to the crops. The most frequently applied agrochemicals included: organophosphates, organochlorines, carbamates, glyphosate, pyrethroids, triazine, acetamides, benzimidazoles and bipyridyls.

\section{Participants}

For the cross-sectional study, 72 schoolchildren of Rivas Davila municipality were randomly selected in the elementary school of Las Tapias village, between 6 and 12 years old ( $9 \pm 2$ years old), 40 males and 32 females. For control group, 41 schoolchildren, 20 males and 21 females, who had no history of pesticide exposure, with similar age ( $9 \pm 2$ years old) and educational level as the exposed children, were randomly recruited in an elementary school in Merida City, located at $1600 \mathrm{~m}$ above sea level, Merida state, Venezuela. The longitudinal study was done two years later, to follow-up the health status of the children who resulted with altered hematological parameters. Only 59\% (20/34) showed up for clinical and medical control, therefore, the variation results were estimated from the 20 children who participated in the follow-up study.

The Ethics Committee of the Council of Scientific, Humanistic, Technologic and Artistic Development of the University of Los Andes, Merida State, Venezuela, reviewed and approved the research protocol. An informed written consent was obtained from the participant children and their legal guardians.

\section{Anthropometry and nutritional assessment}

Information about demographic data of children participants were recorded and anthropometric as well as clinical measurements were collected, based on the techniques recommended by the United Nations International Biological Program [41]. An anthropometric evaluation was performed by obtaining the height, weight, waist circumference and tricipital skinfold. Body mass index (BMI) and body fat percentages were calculated to define nutritional status, based on the World Health Organization charts, adopted by the Anthropometric and Nutritional Status Assessment Workshop for the Nutrition Surveillance System (SISVAN) of the National Institute of Nutrition, which establishes cutoffs for normality between P10 and P90 percentiles [42,43]. A dietary assessment was performed through the 24-hour recalls and the frequency of food consumption [44].

\section{Blood collection for hematological, biochemical and hormone analysis}

After a 12-h overnight fast, $5 \mathrm{ml}$ of blood was drawn, $2 \mathrm{ml}$ of blood in EDTA vacutainers for complete hemogram and $3 \mathrm{ml}$ of blood in plain vacutainers for biochemical tests. The hematological assessment included complete blood counts performed on a fully automated Mindray BC-2600 Auto Hematology Analyzer (Beckman, Inc., U.S.A.). The peripheral smears were stained with Leishman stain and studied by a hematologist. Hematological profile included number of red blood cells (RBC), hemoglobin $(\mathrm{Hb})$, hematocrit (HCT), white blood cells (WBC), lymphocytes, neutrophils, and the mixed cell population of monocytes, eosinophils, basophils, blasts and other precursor white cells.

The biochemical parameters were estimations for liver involvement (aspartate aminotransferase (AST) and alanine aminotransferase (ALT)), renal function (uric acid and creatinine), lipid (cholesterol and triglycerides) and glucose metabolism (glycemia). Analyses were performed on an Omega IV, Model 3305, Semi-automatic Biochemistry Analyzer (Labomed, Inc., U.S.A.).

Plasma was collected for butyrylcholinesterase (BuChE) analysis using a portable field kit (Test-mate EQM Research, Cincinnati, $\mathrm{OH}$, USA), based on the method of Ellman et al. [45], and data were expressed as $\mu \mathrm{mol} / \mathrm{min} / \mathrm{ml}$ plasma $(\mathrm{U} / \mathrm{ml})$. Serum was separated and kept frozen until assayed for thyroid-stimulating hormone (TSH) and free thyroxine (FT4) by enzymatic immunoassay using ELISA kits (Right Choice Diagnostics, Muenster, Germany).

Total antioxidant capacity (TAC) was determined by the FRAP (ferric reducing antioxidant power) assay, based on the reduction of a ferric-tripyridyltriazine ( $\mathrm{Fe}^{3+}$-TPTZ) complex to the ferroustripyridyltriazine $\left(\mathrm{Fe}^{2+}-\mathrm{TPTZ}\right)$ form in the presence of antioxidants [46]. The end product $\left(\mathrm{Fe}^{2+}\right.$-TPTZ) has blue color with absorption maximum at $593 \mathrm{~nm}$ and the change of absorbance is related to the antioxidant capacity of the plasma.

\section{Statistical analysis}

Data are presented as means \pm SD and were analyzed by One-way ANOVA or Student's t-test, followed by Dunnett's test for comparisons between control and exposed groups. $\mathrm{P}<0.05$ was considered statistically significant. The magnitude of the difference between two groups was also determined by calculating Cohen's $d$ effect size from t-tests $[47,48]$. Cohen's $d$ effect sizes are classified as small $(d=0.2)$, medium $(d=0.5)$ and large $(d \geq 0.8)$. All statistical analyses were performed using GraphPad In Stat tm, version $2.04 \mathrm{a}$ software.

\section{Results}

The participants showed no significant differences, in terms of mean \pm SD between the exposed and control groups, in age $(9 \pm 2$ years for both groups), weight ( $29 \pm 10$ versus $36 \pm 12 \mathrm{~kg}$, respectively), height (131 \pm 12 versus $137 \pm 12 \mathrm{~cm}$, respectively), and body mass index 
Citation: Miranda-Contreras L, Osuna JA, Cruz I, Morales Y, Camacho N, et al. (2017) Altered Hematological and Biochemical Parameters in Schoolchildren Living in an Agricultural Community of Merida State, Venezuela. J Environ Anal Toxicol 7: 431. doi: 10.4172/21610525.1000431

Page 3 of 7

$\left(16.4 \pm 3.3\right.$ versus $18.4 \pm 3.8 \mathrm{~kg} / \mathrm{m}^{2}$, respectively), as shown in Table 1. Most of the children had normal growth rate $(75.1 \%$ versus $91.4 \%$, between exposed and control groups, respectively). Fifteen percent of farm children showed low growth rate compared to about $2.9 \%$ of control group, and $10 \%$ of exposed children exhibited high growth rate compared to $5.7 \%$ of control. About half of participant children of both groups had normal dietary intake; however, a prevalence of malnutrition (31.4\%) was observed in urban-resident children, whereas a higher percentage of undernutrition (20\%) was seen in farm children compared to control.

The mean values of nine hematological parameters are summarized in Table 2. Total RBC count was significantly higher in exposed children than control group, whereas no significant difference was found in WBC count. Farm children had significantly lower $(\mathrm{p}<0.0001) \mathrm{Hb}$ and HCT levels although both mean values were within the normal range. Forty eight percent of the exposed children had platelet counts above the upper limit of normality $\left(>450 \times 10^{3} / \mu \mathrm{L}\right)$. Severity of thrombocytosis was graded as follows: mild $\left(450 \times 10^{3} / \mu \mathrm{L}-700 \times 10^{3} / \mu \mathrm{L}\right)$; moderate $\left(700 \times 10^{3} / \mu \mathrm{L}-900 \times 10^{3} / \mu \mathrm{L}\right)$; and severe $\left(>900 \times 10^{3} / \mu \mathrm{L}\right)[49]$. Forty six percent of farm children had mild thrombocytosis, $1 \%$ with moderate and $1 \%$, severe thrombocytosis, whereas all control children had normal platelet counts (Table 3). Children with thrombocytosis had mean platelet count of $561 \pm 113 \times 10^{3} / \mu \mathrm{L}$ and mean platelet volume (MPV) of $9.5 \pm 0.8 \mathrm{fL}$.

Mean relative lymphocyte counts of farm children were significantly higher $(\mathrm{p}<0.0012)$ than those of urban children, however, the absolute values were not different from control (Table 2). Both relative and absolute mean monocyte counts were significantly increased ( $\mathrm{p}<0.0001 ; d=1.9$ and 1.3 , respectively) in the exposed children. Mean relative neutrophil counts were significantly decreased $(\mathrm{p}<0.0001 ; d=-$ 1.2 ) in farm children compared to control. Although the mean absolute neutrophil counts were significantly lower $(\mathrm{p}<0.0001 ; d=-0.9)$ than control, the values were within reference limits.

In the present study, clinical examination of children participants revealed a high incidence (38\%) of dental caries in the exposed group. One third (33\%) of the children with tooth decay had thrombocytosis, $30 \%$ with lymphocytosis, $26 \%$ with neutropenia, and $19 \%$ had both lymphocytosis and neutropenia. The terms lymphocytosis and neutropenia refer to absolute lymphocyte and neutrophil counts, above or below normal limits by age, respectively. Based on interviews, the most common symptoms reported by farm children and their parents included headaches (33\%), dizziness (19\%), respiratory problems (18\%), diarrhea (13\%), and abdominal pains (8\%); these symptoms are associated with mild exposures to OP and CB insecticides. Assay of plasma cholinesterase activity indicated that $35 \%$ of farm children had been exposed to OP and CB pesticides (Table 4). According to clinical category of enzyme inhibition, based on the study of Rajapakse et al. [50], 10\% of these children had mild inhibition, with their mean BuChE activity $(1.6 \pm 0.2 \mathrm{U} / \mathrm{ml})$ decreased by about $45 \%$ from mean control values $(2.9 \pm 0.5 \mathrm{U} / \mathrm{ml})$. However, it should be pointed out that the agrochemicals used in the region included not only OPs and CBs but also mixtures of other chemical groups of pesticides.

For the biochemical analysis of the sera (Table 4), tests for ALT and AST were within normal ranges in both farm- and urban-resident children, however, mean ALT was significantly lower $(\mathrm{p}=0.0003)$ by 1.6 -fold in exposed group compared with control. There was a significant difference in blood creatinine $(p=0.0006)$ but not in uric acid concentrations between exposed and control groups, however, results were also within normal limits. Blood glucose and total lipids were comparable between the two studied groups, although, mean triglyceride level was significantly lower $(\mathrm{p}<0.0001)$ by $30 \%$ in exposed children compared with control. Both TSH and FT4 levels were found within the reference ranges, however, mean FT4 concentration was significantly lower $(\mathrm{p}=0.0009)$ in exposed children compared with control. TAC levels were significantly different between farm- and urban-resident children $(437 \pm 89 \mu \mathrm{mol} / \mathrm{L}$ versus $1152 \pm 323 \mu \mathrm{mol} / \mathrm{L}$, respectively, $\mathrm{p}<0.0001, d=-3.5)$.

Children with platelet counts $>450 \times 10^{3} / \mu \mathrm{L}$ (thrombocytosis group) showed lymphocytosis (87\%), monocytosis (43\%) and neutropenia $(73 \%)$. Two years later, follow-up of 20 children of thrombocytosis group showed normalized platelet counts, which was significantly reduced $(\mathrm{p}=0.0001)$ by $37 \%$, from baseline levels of 575 \pm 144 to $381 \pm 45 \times 10^{3} / \mu \mathrm{L}$ (Table 5 ). RBC parameters were within normal levels. However, significantly lower values were observed for absolute lymphocyte counts $\left(3.2 \pm 0.7 \times 10^{3} / \mu \mathrm{L}\right.$ versus $2.5 \pm 0.4 \times 10^{3} /$ $\mu \mathrm{L}$, respectively, $\mathrm{p}=0.0004)$, relative neutrophil $(47.0 \pm 8.1 \%$ versus 41.0 $\pm 9.0 \%$, respectively, $p=0.03)$ as well as absolute counts $(3.3 \pm 1.1 \times$ $10^{3} / \mu \mathrm{L}$ versus $2.3 \pm 0.8 \times 10^{3} / \mu \mathrm{L}$, respectively, $\left.\mathrm{p}=0.002\right)$. Conversely, significantly higher values were observed for relative monocyte $(7.5 \pm$ $1.6 \%$ versus $10.5 \pm 2.2 \%$, respectively, $\mathrm{p}=0.0001)$ and absolute counts $\left(0.5 \pm 0.2 \times 10^{3} / \mu \mathrm{L}\right.$ versus $0.6 \pm 0.1 \times 10^{3} / \mu \mathrm{L}$, respectively, $\left.\mathrm{p}<0.05\right)$.

\section{Discussion}

In this study, we have shown alterations in various hematological and biochemical parameters of farm-resident children chronically exposed to the toxic effects of agrochemicals. Of main concern were the most frequently used pesticides such as: mancozeb, cymoxanil, glyphosate, methomyl, paraquat, chlorothalonil, chlorpyrifos, propamocarb, diazinon, carbendazim, carbofuran, malathion and atrazine, among the list of 54 active ingredients applied in the region during the study period, between 2012 and 2014. The most important hematological findings were significantly increased mean platelet counts in about half of the farm children participants in the study. These children had significantly increased lymphocyte and monocyte counts, in contrast, decreased neutrophil counts, suggesting a dysregulation of their immune system. With regard biochemical parameters, although significant differences were observed between exposed and control groups, most of the results were within normal limits. However, TAC values of farm children were significantly reduced compared to control, which could be due to dietary deficiency and to some extent, chronic exposure to adverse health effects of pesticides.

\begin{tabular}{|c|c|c|}
\hline Variable & $\begin{array}{l}\text { Control group } \\
\qquad(N=41)\end{array}$ & $\begin{array}{l}\text { Exposed group } \\
(\mathrm{N}=72)\end{array}$ \\
\hline Age (years) & $9 \pm 2$ & $9 \pm 2$ \\
\hline Weight (kg) & $36 \pm 12$ & $29 \pm 10$ \\
\hline Height (cm) & $137 \pm 12$ & $131 \pm 12$ \\
\hline Body mass index $\left(\mathrm{kg} / \mathrm{m}^{2}\right):{ }^{\dagger}$ Males & $19.0 \pm 3.9$ & $17.4 \pm 4.4$ \\
\hline "Females & $17.8 \pm 3.4$ & $16.8 \pm 3.2$ \\
\hline \multicolumn{3}{|l|}{ Growth rate, $(\%)$ : } \\
\hline Normal & $91.4 \%$ & $75.1 \%$ \\
\hline Low & $2.9 \%$ & $15.0 \%$ \\
\hline High & $5.7 \%$ & $10.0 \%$ \\
\hline \multicolumn{3}{|l|}{ Nutritional diagnosis, (\%): } \\
\hline Normal & $57.1 \%$ & $55.0 \%$ \\
\hline Obese & $17.1 \%$ & $8.3 \%$ \\
\hline Overweight & $14.3 \%$ & $6.7 \%$ \\
\hline Undernutrition & $11.5 \%$ & $20.0 \%$ \\
\hline
\end{tabular}

Table 1: Anthropometry and nutritional diagnosis of control and exposed groups. 
Citation: Miranda-Contreras L, Osuna JA, Cruz I, Morales Y, Camacho N, et al. (2017) Altered Hematological and Biochemical Parameters in Schoolchildren Living in an Agricultural Community of Merida State, Venezuela. J Environ Anal Toxicol 7: 431. doi: 10.4172/21610525.1000431

Page 4 of 7

\begin{tabular}{|c|c|c|c|c|c|}
\hline Parameters & Reference Value & $\begin{array}{c}\text { Control group } \\
(N=41)\end{array}$ & $\begin{array}{l}\text { Exposed group } \\
(\mathrm{N}=72)\end{array}$ & 'Cohen's $d$ & ${ }^{*} p$ value \\
\hline Red blood cells $\times 10^{3} / \mu \mathrm{L}$ & $4.0-5.4$ & $5.0(0.3)$ & $5.2(0.3)$ & 0.7 & 0.0009 \\
\hline Hemoglobin g/dL & $11.5-16.5$ & $15.7(1.0)$ & $14.3(0.8)$ & -1.6 & $<0.0001$ \\
\hline Hematocrit (g/dl) & $35.0-49.0$ & $44.6(2.5)$ & $42.4(2.8)$ & 2.7 & $<0.0001$ \\
\hline Platelets $\times 10^{3} / \mu \mathrm{L}$ & $150-450$ & $320(59)$ & $460(134)$ & 1.3 & $<0.0001$ \\
\hline Mean platelet volume (fL) & $7.4-8.1$ & $7.6(0.5)$ & $9.9(1.1)$ & 0.9 & $<0.0001$ \\
\hline White blood cells $\times 10^{3} / \mu \mathrm{L}$ & $4.5-10.0$ & $8.0(2.2)$ & $7.6(1.8)$ & -0.2 & 0.3 \\
\hline Lymphocytes (\%) & $25.0-33.0$ & $36.9(8.1)$ & $43.5(11.1)$ & 0.6 & 0.0012 \\
\hline Lymphocytes $\times 10^{3} / \mu \mathrm{L}$ & $1.5-3.0$ & $2.9(0.7)$ & $3.1(0.9)$ & 0.2 & 0.28 \\
\hline Monocytes (\%) & $3.0-7.0$ & $4.3(1.1)$ & $8.5(2.7)$ & 1.9 & $<0.0001$ \\
\hline Monocytes $\times 10^{3} / \mu \mathrm{L}$ & $0.3-0.8$ & $0.3(0.1)$ & $0.6(0.2)$ & 1.3 & $<0.0001$ \\
\hline Neutrophils (\%) & $54.0-62.0$ & $58.8(8.3)$ & $47.7(9.5)$ & -1.2 & $<0.0001$ \\
\hline Neutrophils $\times 10^{3} / \mu \mathrm{L}$ & $3.0-6.0$ & $4.8(1.9)$ & $3.4(1.3)$ & -0.9 & $<0.0001$ \\
\hline
\end{tabular}

* $p$ : Unpaired Student's T Test, $p<0.05$ considered significant.

tCohen's $d$ effect size from t-tests. Sullivan and Feinn.

Table 2: Mean value ( SD) of hematological parameters in control and exposed groups.

\begin{tabular}{|c|c|c|c|}
\hline Platelet count & ${ }^{*}$ Clinical category of thrombocytosis & $\begin{array}{c}\text { Control group } \\
n(\%)\end{array}$ & $\begin{array}{c}\text { Exposed group } \\
n(\%)\end{array}$ \\
\hline$>150-450 \times 10^{3} / \mu \mathrm{L}$ & Normal & $41(100)$ & $38(53)$ \\
\hline$>450-<700 \times 10^{3} / \mu \mathrm{L}$ & Mild & 0 & $32(44)$ \\
\hline$>700-<900 \times 10^{3} / \mu \mathrm{L}$ & Moderate & 0 & $1(1)$ \\
\hline$>900 \times 10^{3} / \mu \mathrm{L}$ & Severe & 0 & $1(1)$ \\
\hline
\end{tabular}

${ }^{a} \mathrm{~N}=41 ;{ }^{\mathrm{b}} \mathrm{N}=72$; ${ }^{*}$ Chiarello et al.

Table 3: Distribution of blood platelet counts in control and exposed groups.

\begin{tabular}{|c|c|c|c|c|c|}
\hline Parameters & Reference Value & $\begin{array}{l}\text { Control group } \\
(\mathrm{N}=41)\end{array}$ & $\begin{array}{l}\text { Exposed group } \\
(\mathrm{N}=72)\end{array}$ & tEffect Size & * $p$ \\
\hline Serum Aspartate Aminotransferase, U/L & $1-37$ & $18(7)$ & $17(5)$ & -0.2 & 0.4 \\
\hline Serum Alanine Aminotransferase, U/L & $1-42$ & $13(8)$ & $8(6)$ & -0.8 & 0.0003 \\
\hline Blood Creatinine, mg/dL & $0.5-1.5$ & $0.6(0.2)$ & $0.5(0.1)$ & -0.7 & 0.0006 \\
\hline Blood Uric Acid, mg/dL & $3.5-7.2$ & $3.3(1.0)$ & $3.7(1.2)$ & 0.4 & 0.07 \\
\hline Blood Glucose, mg/dL & $70-110$ & $91(7)$ & $91(8)$ & 0 & 1.0 \\
\hline Total Cholesterol, mg/dL & $130-200$ & $154(24)$ & $157(23)$ & 0.1 & 0.51 \\
\hline Triglycerides, mg/dL & $36-150$ & $95(44)$ & $67(25)$ & -0.9 & $<0.0001$ \\
\hline Thyroxine, ng/dL & $0.8-2.0$ & $1.6(0.3)$ & $1.4(0.3)$ & -0.7 & 0.0009 \\
\hline Thyroid Stimulating Hormone, $\mu \mathrm{IU} / \mathrm{mL}$ & $0.3-8.1$ & $2.8(0.9)$ & $2.5(1.5)$ & 0.1 & 0.25 \\
\hline Plasma Cholinesterase (U/mL) & $2.4-3.64$ & a $2.9(0.5)$ & ${ }^{\mathrm{b}} 2.6(0.6)$ & -0.5 & 0.015 \\
\hline Total Antioxidant Capacity, $\mu \mathrm{mol} / \mathrm{L}$ & $\geq 700$ & $1152(323)$ & $437(89)$ & -3.5 & $<0.0001$ \\
\hline
\end{tabular}

" $\mathrm{p}$ : Unpaired Student's $\mathrm{t}$ test, $\mathrm{p}<0.05$ considered significant.

tCohen's $d$ effect size from t-test

${ }^{\mathrm{a}} \mathrm{N}=38 ;{ }^{\mathrm{b}} \mathrm{N}=61$

Table 4: Mean value (SD) of biochemical parameters in control and exposed groups.

\begin{tabular}{|c|c|c|c|c|}
\hline Parameters & $\begin{array}{l}\text { Baseline } \\
\qquad \mathrm{N}=\mathbf{2 0}\end{array}$ & $\begin{array}{l}\text { Follow-up } \\
\qquad \begin{array}{l}\mathrm{N}=\mathbf{2 0}\end{array}\end{array}$ & $\begin{array}{c}\text { Change } \\
\text { (baseline - follow-up) }\end{array}$ & ${ }^{*} p$ value \\
\hline Red blood cells $\times 10^{3} / \mu \mathrm{L}$ & $5.1 \pm 0.3$ & $5.0 \pm 0.3$ & $0.2 \pm 0.3$ & 0.3 \\
\hline Hemoglobin g/dL & $14.1 \pm 0.6$ & $14.8 \pm 0.7$ & $-0.7 \pm 0.6$ & 0.002 \\
\hline Platelets $\times 10^{3} / \mu \mathrm{L}$ & $575 \pm 144$ & $381 \pm 45$ & $194 \pm 120$ & 0.0001 \\
\hline White blood cells $\times 10^{3} / \mu \mathrm{L}$ & $7.0 \pm 1.4$ & $5.4 \pm 1.0$ & $1.6 \pm 1.6$ & 0.0002 \\
\hline Lymphocytes (\%) & $45.4 \pm 8.1$ & $46.9 \pm 7.1$ & $-1.5 \pm 9.5$ & 0.5 \\
\hline Lymphocytes $\times 10^{3} / \mu \mathrm{L}$ & $3.2 \pm 0.7$ & $2.5 \pm 0.4$ & $0.7 \pm 1.0$ & 0.0004 \\
\hline Monocytes (\%) & $7.5 \pm 1.6$ & 10.52 .2 & $-3.1 \pm 3.1$ & 0.0001 \\
\hline Monocytes $\times 10^{3} / \mu \mathrm{L}$ & $0.5 \pm 0.2$ & $0.6 \pm 0.1$ & $-0.04 \pm 0.2$ & 0.05 \\
\hline Neutrophils (\%) & $47.0 \pm 8.1$ & $41.0 \pm 9.0$ & $6.0 \pm 10.7$ & 0.03 \\
\hline Neutrophils $\times 10^{3} / \mu \mathrm{L}$ & $3.3 \pm 1.1$ & $2.3 \pm 0.8$ & $1.1 \pm 1.2$ & 0.002 \\
\hline
\end{tabular}

"p: Paired Student's t test; $p<0.05$ considered significant.

Table 5: Comparison of hematological parameters of exposed children after two years follow-up. 
Citation: Miranda-Contreras L, Osuna JA, Cruz I, Morales Y, Camacho N, et al. (2017) Altered Hematological and Biochemical Parameters in Schoolchildren Living in an Agricultural Community of Merida State, Venezuela. J Environ Anal Toxicol 7: 431. doi: 10.4172/21610525.1000431

Page 5 of 7

A high percentage $(46 \%)$ of the children living in the studied agricultural community of Merida had thrombocytosis, generally considered a platelet count of more than $450 \times 10^{3} / \mu \mathrm{L}$. According to Kucine et al. [51], thrombocytosis is now a common finding in the complete blood count of children. It is often transient and occurs secondary to various underlying medical disorders, usually inflammatory, because an increase in the platelet count is one aspect of the acute phase reaction. This occurs more frequently in younger children, either because of the immaturity of their innate and/or adaptive immunity, or because they have more frequent infections [51]. According to its origin, thrombocytosis is classified into primary and secondary forms. Primary thrombocytosis is an extremely rare clonal disease in childhood with an incidence of one per million children; the platelet count is generally above $1000 \times 10^{3} / \mu \mathrm{L}$ and may be associated with hemorrhagic events. Secondary or reactive thrombocytosis is very common in pediatric age and is due to a variety of conditions, such as bacterial and viral infections, inflammatory diseases, recent surgery, malignancy, iron, vitamin E and B12 deficiency, hemolytic anemia, allergic reactions, nephritis, pancreatitis, and side effects of some medications [51]. From the interviews conducted with the parents of farm children, all of them were either occupationally or environmentally exposed to pesticides; hence, there was concern of the increased risk of these children to develop inflammatory or malignant diseases in childhood or later in life. Epidemiologic studies have consistently shown elevated risks of leukemia, brain cancer, Wilms' tumor, Ewing's sarcoma, and germ cell tumors in childhood, observed for children whose parents had occupational exposures to pesticides $[11,12,16,17,52]$. Therefore we tried to evaluate the underlying causes of altered hematological parameters in the exposed children, particularly the high incidence of secondary thrombocytosis, increased lymphocytes counts and decreased neutrophil levels, as compared with control.

The hematological results of farm children showed significantly increased mean RBC and platelet counts; in contrast, significantly decreased mean $\mathrm{Hb}$ and HCT concentrations compared with the control group (Table 2). It has been reported that at high altitude, adaptation mechanisms to hypoxic condition alter hematological parameters causing increments in RBC counts, $\mathrm{Hb}$ and HCT concentrations, while platelet counts decline with increasing altitude $[53,54]$. Our results were not consistent with those reported by others. Although the values were within normal limits, significant differences observed for mean RBC indices between exposed and control groups could be related to dissimilarities in their dietary intake. In this study, $20 \%$ of farm children suffered mild to severe undernutrition, $7 \%$ obesity and $6 \%$ overweight, compared to control group, which showed $12 \%$ mild undernutrition, $17 \%$ obesity and $14 \%$ overweight (Table 1 ). In developing countries, the coexistence of nutritional deficit and excess, or "double burden" of malnutrition, is prevalent [55]. In Venezuela, 21$28 \%$ of children between 7 and 17 years old are overweight and $15-17 \%$ are undernourished; this fact is a reflection of the "double burden", in which the prevalence of undernourished children is greater than that of overweight, particularly in rural states of lower socioeconomic strata [55]. Undernutrition, protein-energy malnutrition and micronutrient deficiencies are all associated with immune system dysfunction, which increases the vulnerability to infection through impaired immunity [56].

Iron deficiency is most commonly associated with thrombocytosis $[57,58]$. Elevated platelet counts, especially in the setting of iron deficiency, can lead to an increased thromboembolic risk, with clinical consequences especially in patients with inflammatory bowel disease, chronic kidney disease or cancer [59]. Fortunately, none of the farm children showed thromboembolic manifestations during the study period. Based on RBC parameters, the mean $\mathrm{Hb}$ level of the farm children was within the normal limits; moreover, all detected levels were above the established cut-off levels for anemia $(<11.5 \mathrm{~g} / \mathrm{dL})$ for this age group (WHO, 2001), indicating that these children were not anemic. Conversely, iron deficiency can occur with normal $\mathrm{Hb}$ levels and patients often show relatively few symptoms spontaneously [57]. Iron deficiency in children can affect development and lead to anemia; untreated iron deficiency can cause physical and mental delays and increases susceptibility to infections $[60,61]$. However, due to fund limitations, assay of micronutrient deficiency indicators, such as serum ferritin and transferrin, were not included in the study.

The most frequent cause of secondary thrombocytosis in children are bacterial or viral infections; among these infections, respiratory diseases are the most frequent, followed by gastrointestinal and genitourinary [62]. Most of the farm children participants had no symptoms of respiratory illness on the day of sampling. However, physical examination of these children showed a prevalence $(38 \%)$ of dental caries, which could be a source of bacterial infection and chronic inflammation, a possible cause of secondary thrombocytosis. Dental caries is a chronic infectious disease resulting from the penetration of oral bacteria into the enamel and dentin; microorganisms subsequently trigger inflammatory responses in the dental pulp [63]. Childhood dental caries constitutes the single most common chronic disease, affecting as many as $60-90 \%$ of children worldwide between the ages of 2 and 11 years [64]. Many parents, particularly those from low socioeconomic status, are less attentive to the dental hygiene of their children; this is evidenced by the fact that, on medical follow-up two years later, children participants were still found with dental caries. In this report, one third of thrombocytosis cases is associated with dental caries and either an increased absolute lymphocyte count or a decreased absolute neutrophil count or, in a few cases, both lymphocytosis and neutropenia. The abnormal levels of these hematological parameters reflect the defensive mechanism triggered by the dental pulp immune cells against cariogenic bacterial infection into the enamel and dentin [63]. However, if tooth decay was found in only one third of thrombocytosis cases, what then is the etiology behind the elevated platelet counts in the other two thirds of the cases?

Several evidence affirm that pesticide exposure causes dysregulation of the immune system and predisposition to different types of cancers, allergies, autoimmune and infectious diseases [65,66]. Various studies on animal models exposed to specific pesticides have explored changes in hematological and biochemical parameters as possible biomarkers of pesticide exposure before adverse clinical health problems occur [24-29]. More recently, clinical studies on pesticide sprayers have focused on the immunological, hematological and biochemical statuses of these farmers [23,67-71]. However, to our knowledge, there are no published reports on biomonitoring of children living in an agricultural community, where there is a high risk of exposure to the toxic effects of pesticides.

Many of our results were consistent with those reported by others among pesticide-exposed individuals compared to controls, such as: increased levels of Hb, HCT, RBC [67]; increased lymphocyte, monocyte and platelets counts $[68,70,72]$; reduced mean neutrophil counts, serum acetylcholinesterase activity and T4 [70]. Evidence from some animal studies were also consistent with our findings. In rats exposed to increasing concentrations of monocrotophos, an organophosphate insecticide, increased levels of lymphocytes and reduced neutrophils 
Citation: Miranda-Contreras L, Osuna JA, Cruz I, Morales Y, Camacho N, et al. (2017) Altered Hematological and Biochemical Parameters in Schoolchildren Living in an Agricultural Community of Merida State, Venezuela. J Environ Anal Toxicol 7: 431. doi: 10.4172/21610525.1000431

Page 6 of 7

were observed [73]. Neutrophil and lymphocyte counts can be altered by various physiological and pathological processes. In farm children, the observed alterations in both lymphocyte and neutrophils levels could be caused by chronic environmental exposure to pesticides, which have the tendency to destroy neutrophils and as a consequence, overwhelm the defense mechanism of the individuals [65]. This is supported by the fact that the mean TAC level of farm-resident children was significantly reduced as compared with that of urbanresident control children. It is well accepted that stimulation of freeradical production, induction of lipid peroxidation, and disturbance of the total antioxidant capacity of the body are mechanisms of toxicity in most pesticides, including organophosphates, bipiridyl herbicides and organochlorines [74]. In the follow-up study done two years later, the most important finding was the normalization of mean platelet and absolute lymphocyte counts, however, decreased mean absolute neutrophil count was still observed. Nonetheless, the small number of re-evaluated participants strongly limit the significance of the results.

In conclusion, this study demonstrates that children living in an agricultural community are exposed to the health hazards of pesticides, as observed from alterations of hematological and biochemical parameters. Undernutrition and improper dental hygiene affect children's overall health status and are likely to increase their vulnerability to the toxic effects of pesticides.

\section{Acknowledgements}

This work was supported by the Council of Scientific, Humanistic, Technologic and Artistic Development of the University of Los Andes, Merida State, Venezuela (CDCHTA) under Grants M-1004-10-07-B; and National Fund of Science, Technology and Innovation of Venezuela (FONACIT) under Grant S1-2002000281.

\section{References}

1. Roberts JR, Karr CJ (2012) Pesticide exposure in children. Pediatrics 130 e1765-e1788.

2. Laborde A, Tomasina F, Bianchi F, Bruné MN, Buka I, et al. (2015) Children's health in Latin America: the influence of environmental exposures. Environ Health Perspect 123: 201-209.

3. Jurewicz J, PolaÅka K, Hanke W (2013) Chemical exposure early in life and the neurodevelopment of children--an overview of current epidemiological evidence. Ann Agric Environ Med 20: 465-486.

4. Gonzalez-Alzaga B, Lacasaña M, Aguilar-Garduño C, Rodriguez-Barranco M Ballester F, et al. (2014) A systematic review of neurodevelopmental effects of prenatal and postnatal organophosphate pesticide exposure. Toxicol Lett 230: 104-121.

5. Shelton JF, Geraghty EM, Tancredi DJ, Delwiche LD, Schmidt RJ, Ritz B, et al. (2014) Neurodevelopmental disorders and prenatal residential proximity to agricultural pesticides: the CHARGE study. Environ Health Perspect 122: 1103-1109.

6. Andersen HR, Debes F, Wohlfahrt-Veje C, Murata K, Grandjean P (2015) Occupational pesticide exposure in early pregnancy associated with sexspecific neurobehavioral deficits in the children at school age. Neurotoxicol Teratol 47: 1-9.

7. Oulhote $Y$, Bouchard MF (2013) Urinary metabolites of organophosphate and pyrethroid pesticides and behavioral problems in Canadian children. Environ Health Perspect 121: 1378-1384.

8. Raanan R, Harley KG, Balmes JR, Bradman A, Lipsett M, et al. (2015) Early-life exposure to organophosphate pesticides and pediatric respiratory symptoms in the CHAMACOS cohort. Environ Health Perspect 123: 179-185.

9. Flower KB, Hoppin JA, Lyn CF, Blair A, Knott C, et al. (2004) Cancer risk and parental pesticide application in children of agricultural health study participants. Environ Health Perspect 112: 631-635.

10. Vinson F, Merhi M, Baldi I, Raynal H, Gamet-Payrastre L (2011) Exposure to pesticides and risk of childhood cancer: a meta-analysis of recent epidemiological studies. Occup Environ Med 68: 694-702.
11. Cha ES, Hwang S, Lee J (2014) Childhood leukemia mortality and farming exposure in South Korea: A national population-based birth cohort study. Cancer Epidemiol 38: 401-407.

12. Kunkle B, Bae S, Singh KP, Roy D (2014) Increased risk of childhood brain tumors among children whose parents had farm-related pesticide exposures during pregnancy. JP Journal of Biostatistics 11: 89.

13. US Cancer Statistics Working Group. United States Cancer Statistics (2016) 1999-2013 Incidence and Mortality Web-based Report. Atlanta: US Department of Health and Human Services, Centers for Disease Control and Prevention and National Cancer Institute.

14. World Health Organization (2009) Incidence of Childhood Leukemia, an ENHIS Fact Sheet.

15. Capote Negrin LG (2006) Aspectos epidemiológicos del cáncer en Venezuela. Rev Venez Oncol 18: 269-281.

16. Wigle DT, Turner MC, Krewski D (2009) A systematic review and meta-analysis of childhood leukemia and parental occupational pesticide exposure. Environ Health Perspect 117: 1505-1513.

17. Van Maele-Fabry G, Lantin AC, Hoet P, Lison D (2013) Childhood leukemia and parental occupational exposure to pesticides: a systematic review and meta-analysis. Cancer Causes Control 21: 787-809.

18. Maryam Z, Sajad A, Maral N, Zahra L, Sima P, et al. (2015) Relationship between exposure to pesticides and occurrence of acute leukemia in Iran. Asian Pac J Cancer Prev 16: 239-244.

19. Thompson B, Griffith WC, Barr DB, Coronado GD, Vigoren EM, et al. (2014) Variability in the take-home pathway: farmworkers and non-farmworkers and their children. J Expo Sci Environ Epidemiol 24: 522-531.

20. Miranda-Contreras L, Gómez-Pérez R, Rojas G, Cruz I, Berrueta L, et al. (2013) Occupational exposure to organophosphate and carbamate pesticides affects sperm chromatin integrity and reproductive hormone levels among Venezuelan farm workers. J Occup Health 55: 195-203.

21. Singleton ST, Lein PJ, Dadson OA, McGarrigle BP, Farahat FM, et al. (2015) Longitudinal assessment of occupational exposures to the organophosphorous insecticides chlorpyrifos and profenofos in Egyptian cotton field workers. Int Hyg Environ Health 218: 203-211.

22. Abu Mourad T (2005) Adverse impact of insecticides on the health of Palestinian farm workers in the Gaza Strip: a hematologic biomarker study. Int J Occup Environ Health 11: 144-149.

23. Ismail AA, Rohlman DS, Abdel Rasoul GM, Abou Salem ME, Hendy OM (2010) Clinical and biochemical parameters of children and adolescents applying pesticides. Int J Occup Environ Med 1: 132-143.

24. Ambali S, Akanbi D, Igbokwe N, Shittu M, Kawu M, et al. (2007) Evaluation of subchronic chlorpyrifos poisoning on hematological and serum biochemical changes in mice and protective effect of vitamin C. J Toxicol Sci 32: 111-120.

25. Benković V, Đikić D, Grgorinić T, Mladinić M, Željezić D (2012) Haematology and blood chemistry changes in mice treated with terbuthylazine and its formulation Radazin TZ-50. Bull Environ Contam Toxicol 89: 955-959.

26. Begum SA, Upadhyaya TN, Baruah GK, Rahman T, Pathak DC, et al. (2015) Hematobiochemical alterations of acute chlorpyriphos intoxication in indigenous chicken. Vet World, EISSN 8: 2231-0916.

27. Modesto KA, Martinez CBR (2010) Effects of roundup transorb on fish: hematology, antioxidant defenses and acetylcholinesterase activity. Chemosphere 81: 781-787.

28. Gholami-Seyedkolaei SJ, Mirvaghefi A, Farahmand H, Kosari AA (2013) Effect of a glyphosate-based herbicide in Cyprinus carpio: Assessment of acetylcholinesterase activity, hematological responses and serum biochemical parameters. Ecotoxicol Environ Safety 98: 135-141.

29. Yonar SM, Ural MS, Silici S, Yonar ME (2014) Malathion-induced changes in the hematological profile, the immune response, and the oxidative/antioxidant status of Cyprinus carpio carpio: Protective role of propolis. Ecotoxicol Env Safety 102: 202-209.

30. Blanco-Ayala T, Andérica-Romero AC, Pedraza-Chaverri J (2014) New insights into antioxidant strategies against paraquat toxicity. Free Radic Res 48: $623-640$.

31. Peña-Contreras $Z$, Miranda-Contreras L, Morales-Ovalles $Y$, ColmenaresSulbaran M, Davila-Vera D, et al. (2016) Atrazine and mancozeb induce 
Citation: Miranda-Contreras L, Osuna JA, Cruz I, Morales Y, Camacho N, et al. (2017) Altered Hematological and Biochemical Parameters in Schoolchildren Living in an Agricultural Community of Merida State, Venezuela. J Environ Anal Toxicol 7: 431. doi: 10.4172/21610525.1000431

excitotoxicity and cytotoxicity in primary cultures of mouse cerebellar cortex Toxicol Env Chem 98: 959-976.

32. Achudume AC (2012) Analysis of the impacts of environmental pollution of pesticides on oxidative stress profile in liver and kidney: a case of raid $\AA$ in Wistar rat. J Environ Anal Toxicol 2: 124

33. Petrovic S, Bogavac-Stanojevic N, Kotur-Stevuljevic J, Peco-Antic A, Ivanisevic I, et al. (2014) Oxidative status parameters in children with urinary tract infection. Biochem Med (Zagreb) 24: 266-272.

34. Nascimento-Souza MA, Paiva PG, Martino HS, Ribeiro AQ (2016) Dietary total antioxidant capacity as a tool in health outcomes in middle-aged and older adults: a systematic review. Crit Rev Food Sci Nutr.

35. Flores-Garcia ME, Molina-Morales Y, Balza-Quintero A, Benitez-Diaz PR, Miranda-Contreras $L$ (2011) Residuos de plaguicidas en aguas para consumo humano en una comunidad agrícola del estado Merida, Venezuela. Invest Clin 52: $295-310$

36. Molina-Morales Y, Flores-Garcia M, Balza-Quintero A, Benitez-Diaz $P$, Miranda-Contreras L (2012) Niveles de plaguicidas en aguas superficiales de una region agricola del estado Merida, Venezuela, entre 2008 y 2010 . Rev Int Contam Ambie 28: 289-301.

37. Benitez-Diaz P, Miranda-Contreras L (2013) Contaminacion de aguas superficiales por residuos de plaguicidas en Venezuela y otros paises de Latinoamerica. Rev Int Contam Ambie 29: 7-23.

38. Benitez-Diaz P, Miranda-Contreras L, Molina-Morales Y, Sanchez-Gil B, Balza-Quintero A. (2015) Residuos de plaguicidas en cascara y pulpa de papa (Solanum tuberosum L.) cosechada en una region agricola del Estado Merida, Venezuela. Bioagro 27: 27-36.

39. Benitez-Diaz P, Miranda-Contreras L, Balza-Quintero A, Sanchez-Gil B Molina-Morales $Y$ (2015) Residuos de plaguicidas en fresa (fragraria $X$ ananassa) cosechada en una region agricola del estado Merida, Venezuela. Bioagro 27: 183-190.

40. Miranda-Contreras L, Cruz I, Osuna JA, Gomez-Perez R, Berrueta L, et al. (2015) Efectos de la exposicion ocupacional a plaguicidas sobre la calidad del semen en trabajadores de una comunidad agricola del estado Merida, Venezuela. Invest Clin 56: 1-14.

41. Weiner J, Lourie J (1969) Human Biology. A guide to field method. International Biological Programme, Handbook No. 9. Oxford, Blackwell Scientific Publications.

42. Instituto Nacional de Nutricion (2003) Sistema de Vigilancia Alimentario y Nutricional (SISVAN). Boletín Informativo, Caracas, Venezuela.

43. WHO Working Group (1986) Use and interpretation of anthropometric indicators of nutritional status. Bulletin of the World Health Organization 64: 929-941.

44. Zarzalejo Z, Garcia M, Alvarez M, Millan A (1999) La evaluacion dietetica como instrumento diagnostico en la población pediatrica. An Venez Nutr 12: 33-44.

45. Ellman GL, Courtney DK, Andreas V, Featherstone RM (1961) A new and rapid colorimetric determination of acetylcholinesterase activity. Biochem Pharmacol 7: 88-95.

46. Benzie IF, Strain JJ (1996) The ferric reducing ability of plasma (FRAP) as a measure of "antioxidant power": the FRAP assay. Anal Biochem 239: 70-76.

47. Thalheimer W, Cook S (2002) How to calculate effect sizes from published research: A simplified methodology.

48. Sullivan GM, Feinn R (2012) Using Effect Size-or Why the P Value Is Not Enough. J Grad Med Educ 4: 279-282.

49. Chiarello $P$, Magnolia M, Rubino M, Liguori SA, Miniero R (2011) Thrombocytosis in children. Minerva Pediatr 63: 507-513.

50. Rajapakse BN, Thiermann H, Eyer P, Worek F, Bowe SJ, et al. (2011) Evaluation of the Test-mate ChE (cholinesterase) field kit in acute organophosphorus poisoning. Ann Emerg Med 58: 559-564.

51. Kucine N, Chastain KM, Mahler MB, Bussel JB (2014) Primary thrombocytosis in children. Haematologica 99: 620-628.

52. Buckley JD, Robison LL, Swotinsky R, Garabrant DH, LeBeau M, et al. (1989) Occupational exposures of parents of children with acute nonlymphocytic leukemia: a report from the Childrens Cancer Study Group. Cancer Res 49: 4030-4037.
53. Trompetero González AC, Mejia EC, Pinzon WF, Serrato M, Landinez MP, et al. (2015) Behavior of hemoglobin concentration, hematocrit and oxygen saturation in Colombian university population at different altitudes. Nutr Hosp 32: $2309-2318$

54. Goel A, Shrivastava A, Purwar B (2012) Platelet count in permanent residents of high altitude. Indian J Prev Soc Med 43: 264-266.

55. Lopez de Blanco M, Landaeta-Jimenez M, Herrera Cuenca M, Sifontes $Y$ (2014) La doble carga de desnutrición y obesidad en Venezuela. An Venez Nutr 27: 77-87.

56. Bresnahan KA, Tanumihardjo SA2 (2014) Undernutrition, the acute phase response to infection, and its effects on micronutrient status indicators. Adv Nutr 5: 702-711.

57. Bermejo F, García-López S (2009) A guide to diagnosis of iron deficiency and iron deficiency anemia in digestive diseases. World J Gastroenterol 15: 46384643.

58. Subramaniam N, Mundkur S, Kini P, Bhaskaranand N, Aroor S (2014) Clinicohematological study of thrombocytosis in children. ISRN Hematol 2014: 389257.

59. Evstatiev R (1946) Iron deficiency, thrombocytosis and thromboembolism Wiener medizinische Wochenschrift 166: 437.

60. Bermejo F, García-López S (2009) A guide to diagnosis of iron deficiency and iron deficiency anemia in digestive diseases. World J Gastroenterol 15: 46384643.

61. Wang J, Wang $H$, Chang $S$, Zhao $L$, Fu $P$, et al. (2015) The Influence of Malnutrition and Micronutrient Status on Anemic Risk in Children under 3 Years Old in Poor Areas in China. PLoS One 10: e0140840.

62. Mata Fernandez C, Perez-Miranda Castillo J, Galaron Garcia P, Cela de Julian E, Belendez Bielera C (2008) Trombocitosis en la consulta de oncohematologia. Descripcion, diagnostico etiologico y evolucion. An Pediatr (Barc) 69: 10-14.

63. Farges JC, Alliot-Licht B, Renard E, Ducret M, Gaudin A, et al. (2015) Dental pulp defense and repair mechanisms in dental caries. Mediat Inflamm 2015: Article ID 230251, p: 16.

64. Thomas Boyce W, Den Besten PK, Stamperdahl J, Zhan L, Jiang Y, et al. (2010) Social inequalities in childhood dental caries: the convergent roles of stress, bacteria and disadvantage. Soc Sci Med 71: 1644-1652.

65. Dhouib I, Jallouli M, Annabi A, Marzouki S (2016) From immunotoxicity to carcinogenicity: the effects of carbamate pesticides on the immune system. Environ Sci Pollut Res Int 23: 9448-9458.

66. Gangemi S, Gofita E, Costa C, Teodoro M, Briguglio G, et al. (2016) Occupational and environmental exposure to pesticides and cytokine pathways in chronic diseases (Review). Int J Mol Med 38: 1012-1020.

67. Emam SJ, Salehcheh M, Haghighizadeh MH, Jazayeri SMHM (2012) Occupational exposure to pesticides among farmers. Pak J Med Sci 28: 120123.

68. Arafa A, Afify M, Samy N (2013) Evaluation of adverse health effects of pesticides exposure [biochemical and hormonal] among Egyptian farmers. J Appl Sci Res 9: 4404-4409.

69. Fareed M, Pathak MK, Bihari V, Kamal R, Srivastava AK, et al. (2013) Adverse respiratory health and hematological alterations among agricultural workers occupationally exposed to organophosphate pesticides: a cross-sectional study in North India. PLoS One 8: e69755.

70. Yaqub SA, Rahamon SK, Arinola OG (2014) Hematological and immunologica indices in Nigerian farmworkers occupationally exposed to organophosphate pesticides. Eur J Gen Med 11: 109-114.

71. Aroonvilairat S, Kespichayawattana W, Sornprachum T, Chaisuriya $P$, Siwadune T, et al. (2015) Effect of pesticide exposure on immunological hematological and biochemical parameters in Thai orchid farmers a crosssectional study. Int J Environ Res Public Health 12: 5846-5861.

72. Manyilizu WB, Mdegela RH, Kazwala R, Nonga H, Muller M, et al. (2016) Association of long-term pesticide exposure and biologic parameters in female farm workers in Tanzania: a cross sectional study. Toxics 4: 1-12.

73. Sunmonu TO, Oloyede OB (2010) Performance and haematological indices in rats exposed to monocrotophos contamination. Hum Exp Toxicol 29: 845-850.

74. Karami-Mohajeri S, Abdollahi M (2011) Toxic influence of organophosphate, carbamate, and organochlorine pesticides on cellular metabolism of lipids, proteins, and carbohydrates: a systematic review. Hum Exp Toxicol 30: 11191140 . 